\title{
A study on capability of financial ratios in predicting bankruptcy of firms: Evidence from Tehran Stock Exchange
}

\author{
Ghodratollah Janani*, Seyed Ali Nabavi Chashmi and Khosro Faghani Makrani
}

Department Management and Accounting, Science \& Research Branch of Mazandaran, Islamic Azad University, Sari, Iran

\begin{tabular}{l}
\hline C H R O N I C L E \\
\hline Article history: \\
Received January 30, 2013 \\
Received in revised format \\
20 May 2013 \\
Accepted June 22013 \\
Available online \\
June 4 2013 \\
\hline Keywords: \\
Bankruptcy \\
CART \\
Logistic regression \\
Financial ratios
\end{tabular}
\begin{abstract}
A B S T R A C T
This paper measures the likelihood of bankruptcy based on some financial ratios such as debt ratio, current ratio, sales to total assets, etc. using logistic regression and classification and regression tree techniques (CART). The proposed study gathers the information of 36 bankrupted firms and 36 non-bankrupted firms based on Tobin $Q$ ratio. The study gathers the necessary information over the period 2005-2011. The preliminary results indicate that both methods have the capability to predict bankruptcy but with different accuracy. The likelihood of bankruptcy based on CART method were 97.2, 97.2 and 86.1 in the event of bankruptcy, one year before and two years prior to bankruptcy, respectively. These figures were changes to 98.6, 94.4 and 84.7 based on logistic method.
\end{abstract}

\section{Introduction}

The issue of important bankruptcy cases has created motivation and interest in corporate bankruptcy prediction techniques since the 1960s (Takahashi et al., 1984; Mensah, 1984; Adler, 1993). Altman (1968) is believed as one of the pioneers who proposed a method, which has been widely implemented by many people around the world. There are many studies devoted to this subject by most of them are now obsolete. They do not offer a comprehensive comparison of the various approaches towards bankruptcy prediction and mostly fail to provide a remedy to the problem of model choice in empirical application. Aziz and Dar (2006) provided a comprehensive study of the techniques and empirical findings from these techniques in their applications across ten various countries. The predictive accuracies of various techniques appear to be generally comparable, although artificially intelligent expert system techniques performed marginally better than statistical and theoretical techniques. Individually, the implementation of multiple discriminant analysis (MDA) and logit models were used.

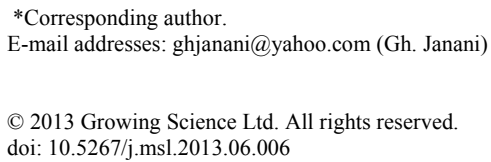


Etemadi et al. (2009) investigated application of geometric programming (GP) for bankruptcy prediction modeling and classified 144 bankrupt and non-bankrupt Iranian firms listed in Tehran stock exchange (TSE). They also used a multiple discriminant analysis (MDA) to benchmarking GP model. They used McNemar test and reported that GP approach outperforms MDA to the problem of corporate bankruptcy prediction. Xie et al. (2011) used financial distress prediction based on MDA method for bankruptcy prediction.

Appiah and Abor (2009) implemented relevant financial information of private medium-sized failed and non-failed manufacturing companies in the UK, over the period 1994-2004 to detect whether corporate failure can be predicted by developing a Z-score model. They reported that the net profit margin was superior to the gross profit margin in discriminating between failed and non-failed UK manufacturing firms in terms of its significant contribution to the Z-score, though the latter exceeded the former slightly using the univariate analysis. Lee et al. (1996) presented a neural network technique to forecast bankruptcy likelihood. Youn and $\mathrm{Gu}$ (2010) used artificial neural network model along with a logistic regression model for predicting of Korean lodging firm failures. Liou (2008) presented a survey on how to detect fraudulent financial reports and business failure prediction models. Wu et al. (2010) in a comprehensive study compared all existing methods for prediction of bankruptcy. Tam (1991) used neural network models and the prediction of bank bankruptcy.

Classification and regression tree techniques (CART) has recently become interesting areas of research and three is a growing interest in this area. Brezigar-Masten and Masten (2012) used CARTbased selection of bankruptcy predictors for the logit model. They discussed that balance-sheet data offer good predictors of corporate financial failure and presented a novel predictor selection procedure based on non-parametric CART and examined its performance within a standard logit model. They demonstrated that a simple logit model with dummy variables could create in accordance with the nodes of estimated classification tree outperforms both standard logit technique with step-wise-selected financial ratios, and CART itself. On a population of Slovenian companies their method achieved good rates of precision in out-of-sample bankruptcy prediction. Their selection technique seems to be an efficient method of introducing non-linear impact of predictor variables on the default probability in standard single-index models like logit.

In this paper, we present two methods for prediction of bankruptcy on some selected firms listed on Tehran Stock Exchange using two methods of logistic regression and CART. The organization of this paper first presents details of the proposed study in section 2 while section 3 presents details of our findings and finally concluding remarks are given in the last to summarize the contribution of the paper.

\section{The proposed model}

This paper measures the likelihood of bankruptcy based on financial ratios such as debt ratio, current ratio, sales to total assets, etc. using logistic regression and classification and regression tree techniques (CART). There are two hypotheses associated with the proposed study of this paper as follows,

1. Logistic regression is capable of detecting the likelihood of bankruptcy.

2. Regression tree technique (CART) is capable of detecting the likelihood of bankruptcy.

The study gathers the necessary information over the period 2005-2011. There are five independent variables including Current ratio $\left(\mathrm{X}_{1}\right)$, Total debt to total assets $\left(\mathrm{X}_{2}\right)$, the ratio of working capital to total assets $\left(\mathrm{X}_{3}\right)$, the ratio of net profit before tax to total assets $\left(\mathrm{X}_{4}\right)$ and the ratio of revenue to total assets $\left(\mathrm{X}_{5}\right)$. Therefore, the proposed study considers the following model for the analysis, 
$Y_{i}=\beta_{0}+\beta_{1} X_{1 i}+\beta_{2} X_{2 i}+\beta_{3} X_{3 i}+\beta_{4} X_{4 i}+\beta_{5} X_{5 i}+\varepsilon_{i}$

where $Y_{i}$ is the likelihood of bankruptcy, $\beta_{i}, i=0, \cdots, 5$ are coefficients to be estimated and $\varepsilon_{i}$ represents the residuals. In our study, the shares of all firms must have been actively traded on stock exchange over the period of study, they must have had similar fiscal calendar and reported their financial figures on quarterly basis. We do not consider the information of banks, holding firms and insurance companies. The proposed study gathers the information of 36 bankrupted firms and 36 nonbankrupted firms based on Tobin Q ratio.

\section{The results}

Table 1 summarizes the results of logistic regression on Eq. (1). As we can observe from the results of logistic regression, all coefficients are statistically significance with $\alpha=0.01$. These results hold on the year of bankruptcy, one year and two years prior to bankruptcy.

\section{Table 1}

The summary of regression analysis

\begin{tabular}{cccccc}
\hline & $\begin{array}{c}\text { Independent } \\
\text { variables }\end{array}$ & Coefficient $(\beta)$ & Standard Error & Sig. & df \\
\hline & $\mathrm{X}_{1}$ & -1172.846 & 34868.710 & 0.001 & 1 \\
Year of & $\mathrm{X}_{2}$ & 264.785 & 9481.102 & 0.001 & 1 \\
Bankruptcy & $\mathrm{X}_{3}$ & 1339.393 & 40348.837 & 0.001 & 1 \\
& $\mathrm{X}_{4}$ & -84.465 & 3222.801 & 0.001 & 1 \\
& $\mathrm{X}_{5}$ & -85.166 & 11127.421 & 0.001 & 1 \\
\hline & Intercept & 1070.538 & 33233.117 & 0.001 & 1 \\
One year before & $\mathrm{X}_{1}$ & -6.789 & 12.665 & 0.287 & 1 \\
Bankruptcy & $\mathrm{X}_{2}$ & 17.533 & 7.483 & 5.489 & 1 \\
& $\mathrm{X}_{3}$ & 9.087 & 20.395 & 0.199 & 1 \\
\hline & $\mathrm{X}_{4}$ & -2.497 & 1.709 & 2.135 & 1 \\
\hline Two years & $\mathrm{X}_{5}$ & -13.821 & 9.208 & 0.033 & 1 \\
before & $\mathrm{Intercept}$ & -2.928 & 16.014 & 1.250 & 1 \\
bankruptcy & $\mathrm{X}_{1}$ & -9.958 & 8.908 & 2.140 & 1 \\
& $\mathrm{X}_{2}$ & 6.954 & 4.754 & 0.963 & 1 \\
\hline
\end{tabular}

Table 2 shows the results of examining the accuracy of the proposed study in three consecutive years.

\section{Table 2}

The results of the likelihood of bankruptcy based on logistic regression method

\begin{tabular}{|c|c|c|c|c|c|c|c|c|c|c|c|c|c|}
\hline \multirow{3}{*}{\multicolumn{2}{|c|}{ Observed }} & \multicolumn{3}{|c|}{ Year of bankruptcy } & \multicolumn{3}{|c|}{$\begin{array}{c}\text { One-year prior to } \\
\text { bankruptcy }\end{array}$} & \multicolumn{3}{|c|}{$\begin{array}{c}\text { Two years before } \\
\text { bankruptcy }\end{array}$} & \multicolumn{3}{|c|}{ Average forecasted } \\
\hline & & \multicolumn{2}{|c|}{$\begin{array}{l}\text { Dependent } \\
\text { variable }\end{array}$} & \multirow{2}{*}{$\begin{array}{c}\% \text { of } \\
\text { Accuracy }\end{array}$} & \multicolumn{2}{|c|}{$\begin{array}{c}\text { Dependent } \\
\text { variable }\end{array}$} & \multirow{2}{*}{$\begin{array}{c}\% \text { of } \\
\text { Accuracy }\end{array}$} & \multicolumn{2}{|c|}{$\begin{array}{c}\text { Dependent } \\
\text { variable }\end{array}$} & \multirow{2}{*}{$\begin{array}{c}\% \text { of } \\
\text { Accuracy }\end{array}$} & \multicolumn{2}{|c|}{$\begin{array}{l}\text { Dependent } \\
\text { variable }\end{array}$} & \multirow{2}{*}{$\begin{array}{c}\% \text { of } \\
\text { Accuracy }\end{array}$} \\
\hline & & 0 & 1 & & 0 & 1 & & 0 & 1 & & 0 & 1 & \\
\hline \multirow{2}{*}{$\begin{array}{l}\text { Dependent } \\
\text { variable }\end{array}$} & $\begin{array}{c}\text { Non- } \\
\text { bankrupted }\end{array}$ & 36 & 0 & 100 & 34 & 2 & 94.4 & 30 & 6 & 83.3 & 100 & 8 & 92.6 \\
\hline & Bankrupted & 1 & 35 & 97.2 & 2 & 34 & 94.4 & 5 & 31 & 86.1 & 8 & 100 & 92.6 \\
\hline Accuracy & & & & 98.6 & & & 94.4 & & & 84.7 & & & 92.6 \\
\hline
\end{tabular}

As we can observe from the results of Table 2, logistic regression is capable of predicting of 92.6\% rate of success on average for bankruptcy prediction. The proposed study of this paper has also used 
classification and regression tree techniques (CART) to verify the proposed model and Table 3 summarizes the results of our survey.

Table 3

The results of the likelihood of bankruptcy based on CART method

\begin{tabular}{|c|c|c|c|c|c|c|c|c|c|c|c|c|c|}
\hline \multirow{3}{*}{\multicolumn{2}{|c|}{ Observed }} & \multicolumn{3}{|c|}{ Year of bankruptcy } & \multicolumn{3}{|c|}{$\begin{array}{c}\text { One-year prior to } \\
\text { bankruptcy }\end{array}$} & \multicolumn{3}{|c|}{$\begin{array}{c}\text { Two years before } \\
\text { bankruptcy }\end{array}$} & \multicolumn{3}{|c|}{ Average forecasted } \\
\hline & & \multicolumn{2}{|c|}{$\begin{array}{c}\text { Dependent } \\
\text { variable }\end{array}$} & \multirow{2}{*}{$\begin{array}{c}\% \text { of } \\
\text { Accuracy }\end{array}$} & \multicolumn{2}{|c|}{$\begin{array}{c}\text { Dependent } \\
\text { variable }\end{array}$} & \multirow{2}{*}{$\begin{array}{c}\% \text { of } \\
\text { Accuracy }\end{array}$} & \multicolumn{2}{|c|}{$\begin{array}{c}\text { Dependent } \\
\text { variable }\end{array}$} & \multirow{2}{*}{$\begin{array}{c}\% \text { of } \\
\text { Accuracy }\end{array}$} & \multicolumn{2}{|c|}{$\begin{array}{c}\text { Dependent } \\
\text { variable }\end{array}$} & \multirow{2}{*}{$\begin{array}{c}\% \text { of } \\
\text { Accuracy }\end{array}$} \\
\hline & & 0 & 1 & & 0 & 1 & & 0 & 1 & & 0 & 1 & \\
\hline \multirow{2}{*}{$\begin{array}{l}\text { Dependent } \\
\text { variable }\end{array}$} & $\begin{array}{c}\text { Non- } \\
\text { bankrupted }\end{array}$ & 35 & 1 & 97.2 & 36 & 0 & 100.0 & 27 & 9 & 75 & 98 & 10 & 90.7 \\
\hline & Bankrupted & 1 & 35 & 97.2 & 2 & 34 & 94.4 & 1 & 35 & 97.2 & 4 & 104 & 96.3 \\
\hline Accuracy & & & & 97.2 & & & 97.2 & & & 86.1 & & & 93.5 \\
\hline
\end{tabular}

In addition, Fig. 1 demonstrates details of the implementation of CART on the year of bankruptcy, one year before and two year before bankruptcy occur.

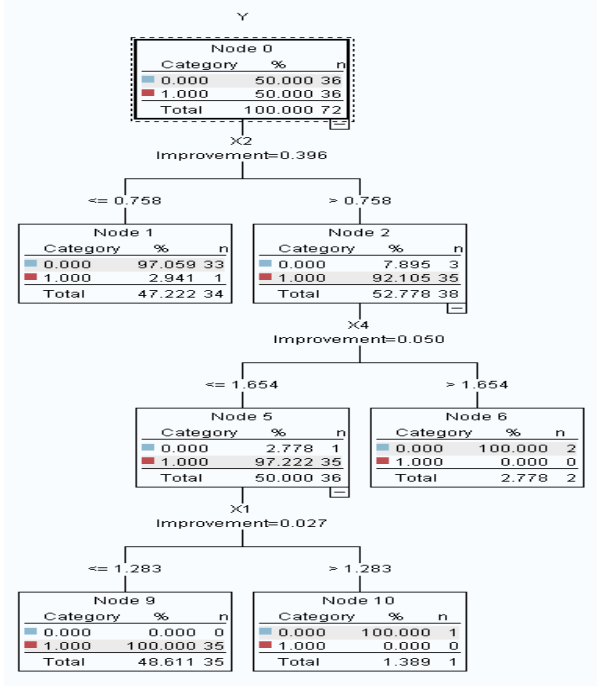

The year of bankruptcy

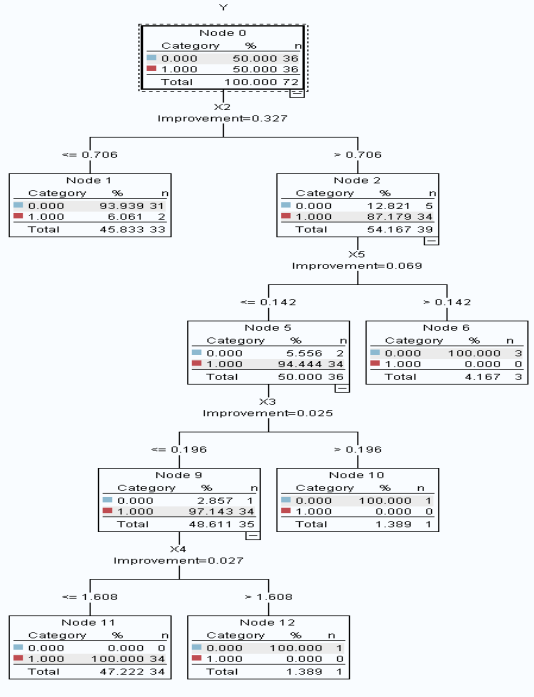

One year before bankruptcy

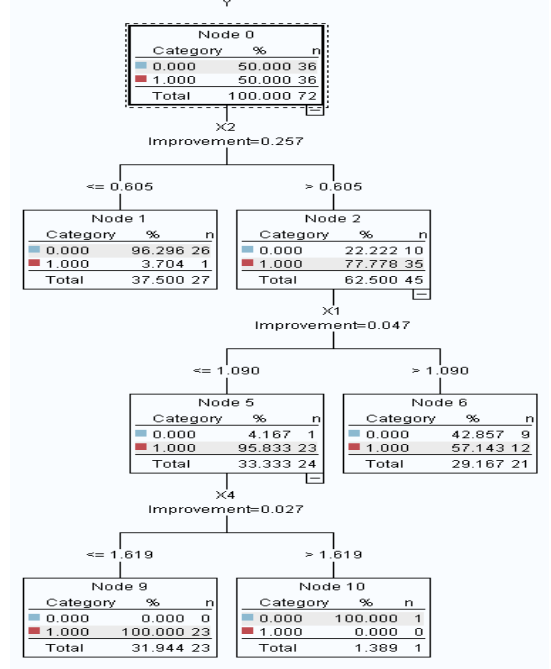

Two years before bankruptcy

Fig. 1. Detailed results of the implementation of CART

As we can observe from the results of Table 4, two methods of have had good rate of success for predicting the rate of bankruptcy.

\section{Table 4}

The summary of the results of logistic regression versus CART method

\begin{tabular}{ccccccccc}
\hline \multirow{2}{*}{$\begin{array}{c}\text { Title } \\
\end{array}$} & \multicolumn{2}{c}{ Year of bankruptcy } & \multicolumn{2}{c}{$\begin{array}{c}\text { One year prior to } \\
\text { bankruptcy }\end{array}$} & \multicolumn{2}{c}{ Two years before } & \multicolumn{2}{c}{ Three years average } \\
& LOGIT & CART & LOGIT & CART & LOGIT & CART & LOGIT & CART \\
\hline Non-bankrupted & 100 & 97.2 & 94.4 & 100 & 83.3 & 75 & 92.6 & 90.7 \\
Bankrupted & 97.2 & 97.2 & 94.4 & 94.4 & 86.1 & 97.2 & 92.6 & 96.3 \\
\hline sum & 98.6 & 97.2 & 94.4 & 97.2 & 84.7 & 86.1 & 92.6 & 93.5 \\
\hline
\end{tabular}

In summary, both hypotheses of this study have been confirmed and we can conclude that logistic regression as well as CART are able to predict bankruptcy, successfully. 


\section{Conclusion}

In this paper, we have presented an empirical investigation to find the effect of five financial figures including Current ratio, Total debt to total assets, the ratio of working capital to total assets, the ratio of net profit before tax to total assets, and the ratio of revenue to total assets for predicting bankruptcy event. The study has implemented two methods of logistic regression as well as CART to forecast bankruptcy event. The results of our survey have indicated that both methods have had the capability to predict bankruptcy event. The results of this survey are consistent with some other studies accomplished in Tehran Stock Exchange by other researchers during the past few years (Moghadam et al., 2005) but the results are not consistent with what Adler (1993) have reported. Presently, in Iran, when a firm encounter a loss where it hurts half of equity is able to file bankruptcy with the government. This law seems to be approximately 50 years old and there is a need to reconsider the rules and regulation and setup some more sophisticated rules and regulation.

As a future study, it is an interesting area of research to consider macroeconomic factors along with firms' financial figures to predict bankruptcy with better precision. Inflation, unemployment and consumer price index are some important factors, which could be considered as part of existing models and we leave it for interested researchers for future studies.

\section{Acknowledgment}

The authors would like to thank the anonymous referees for constructive comments on earlier version of this paper.

\section{References}

Adler, B. E. (1993). Financial and political theories of American corporate bankruptcy. Stanford Law Review, 311-346.

Altman, E. I. (1968). Financial ratios, discriminant analysis and the prediction of corporate bankruptcy. The journal of finance, 23(4), 589-609.

Appiah, K. O., \& Abor, J. (2009). Predicting corporate failure: some empirical evidence from the UK. Benchmarking: An International Journal, 16(3), 432-444.

Aziz, M. A., \& Dar, H. A. (2006). Predicting corporate bankruptcy: where we stand?. Corporate governance, 6(1), 18-33.

Brezigar-Masten, A., \& Masten, I. (2012). CART-based selection of bankruptcy predictors for the logit model. Expert Systems with Applications, 39(11), 10153-10159.

Etemadi, H., Anvary Rostamy, A. A., \& Dehkordi, H. F. (2009). A genetic programming model for bankruptcy prediction: Empirical evidence from Iran. Expert Systems with Applications, 36(2), 3199-3207.

Lee, K. C., Han, I., \& Kwon, Y. (1996). Hybrid neural network models for bankruptcy predictions. Decision Support Systems, 18(1), 63-72.

Liou, F. M. (2008). Fraudulent financial reporting detection and business failure prediction models: a comparison. Managerial Auditing Journal, 23(7), 650-662.

Mensah, Y. M. (1984). An examination of the stationarity of multivariate bankruptcy prediction models: a methodological study. Journal of Accounting Research, 22(1), 380-395.

Moghadam, J., Dastgir, M., \& Sadjadi, S.H. (2005). Predicting firms' bankruptcy using logit model. Economic studies, 171-189.

Takahashi, K., Kurokawa, Y., \& Watase, K. (1984). Corporate bankruptcy prediction in Japan. Journal of Banking \& Finance, 8(2), 229-247.

Tam, K. Y. (1991). Neural network models and the prediction of bank bankruptcy. Omega, 19(5), 429-445. 
Youn, H., \& Gu, Z. (2010). Predicting Korean lodging firm failures: An artificial neural network model along with a logistic regression model. International Journal of Hospitality Management, 29(1), 120-127.

Wu, Y., Gaunt, C., \& Gray, S. (2010). A comparison of alternative bankruptcy prediction models. Journal of Contemporary Accounting \& Economics, 6(1), 34-45.

Xie, C., Luo, C., \& Yu, X. (2011). Financial distress prediction based on SVM and MDA methods: the case of Chinese listed companies. Quality \& Quantity,45(3), 671-686. 